\title{
RANCANG BANGUN MESIN KONVERSI SAMPAH PLASTIK KAPASITAS 3 KG MENJADI BAHAN BAKAR MINYAK
}

\author{
Ikhsan Maulana *1, Indra Wahyu Saputra² \\ 1,2 Teknik, Universitas Singaperbanggsa Karawang \\ 1ikhsanomaulana36@gmail.com
}

\begin{abstract}
ABSTRAK
Sampah plastik merupakan masalah serius yang belum terselesaikan di Indonesia, jika tidak ditanggulangi dengan serius akan mengakibatkan kerusakan lingkungan yang semakin parah. Oleh karena itu harus dilakukan proses recycling sampah plastik. Penelitian ini menggunakan metode pirolisis untuk mengubah plastik menjadi bahan bakar. Jenis plastik yang digunakan adalah PET (polyethylene Terephthalate). Pembuatan alat terdiri dari kompor, ruang pemanasan, ruang pembakaran, kondensor dan ruang filter asap pembakaran. Penelitian ini melakukan proses pembuatan komponen pada alat dengan tahap-tahap sesuai teori perancangan. metode pada alat ini melakukan proses pirolisis, dimana uap hasil pemanasan plastik dimanfaatkan dengan cara didinginkan sehingga merubah fase uap menjadi fase cair atau biasa disebut kondensasi. Pengujian yang dilakukan pada alat menggunakan $3 \mathrm{~kg}$ sampah plastik PET dengan menghitung berapa banyak bahan bakar oli bekas yang di butuhkan dan berapa bahan bakar minyak yang dihasilkan saat alat dioperasikan dalam jangka waktu 60 menit. Dari hasil pengujian didapatkan bakan bakar oli bekas yang dibutuhkan sebanyak $\pm 140 \mathrm{~mL}$ liter dan hasil bahan bakar minyak sebanyak $\pm 140 \mathrm{~mL}$ dalam jangka waktu 60 menit.
\end{abstract}

Kata kunci: bahan bakar minyak, oli bekas, pirolisis, sampah plastik PET, kompor

\begin{abstract}
[Design Of $3 \mathrm{Kg}$ Capacity Plastic Waste Conversion Machine To Be Fuel]. Plastic waste is a serious unresolved problem in Indonesia, otherwise being taken seriously will result in worsening environmental damage. Therefore, the process of recycling plastic waste must be carried out. The study used pyrolysis methods to convert plastic into fuel. The type of plastic used is PET (polyethylene Terephthalate). Tool making consists of stove, heating room, combustion chamber, condenser and combustion smoke filter room. This research conducts the process of making components on the tool with stages according to the theory of design. the method in this tool performs the pyrolysis process, where the steam from plastic heating is utilized by cooling it so that it changes the steam phase into a liquid phase or commonly called condensation. Testing conducted on the tool uses $3 \mathrm{~kg}$ of PET plastic waste by calculating how much used oil fuel is needed and how much fuel oil is produced when the appliance is operated within a period of 60 minutes. From the test results obtained bakan used oil needed as much as $\mathrm{x}$ liters and fuel oil results as much as $\mathrm{x}$ liters in a period of 60 minutes.
\end{abstract}

Keywords: fuel oil; used oil; pyrolysis; PET plastic waste, stove

\section{PENDAHULUAN}

Permasalahan sampah merupakan hal umum yang biasa kita temukan dalam kehidupan seharihari, namun belum dapat bisa ditanggulangi secara masif. Seiring bertambahnya jumlah penduduk maka presentase kenaikan volume akibat sampah juga akan meningkat. Dapat dikatakan 60-70\% sampah organik dan 30-40\% sampah anorganik dihasilkan dari aktivitas penduduk itu sendiri. Sementara itu 14\% dari sampah anorganik adalah sampah plastik. Indonesia menduduki peringkat kedua setelah China yang menghasilkan sampah plastik diperairan sebesar 187,2 Ton. Permasalahan ini jika dibiarkan terus menerus akan berpotensi mencemari lingkungan. Bisa dikatakan sifat plastik dapat terurai di tanah dalam waktu lebih dari 20 tahun hingga 100 tahun, dampaknya adalah dapat menurunkan kesuburan tanah serta akan sulit terurai di perairan [1].

Upaya mengantisipasi permasalahan sampah dan menciptakan lingkungan yang asri dan tertata sudah banyak dilakukan dari tingkat rumah tangga dan lingkungan sampai ke TPA (Tempat Pembuangan 
Akhir). Kebutuhan pasokan energi juga sangat dibutuhkan oleh masyarakat banyak. Para peneliti pun melakukan berbagai cara untuk mendapatkan sumber daya energi baru terbarukan. Karna jika hal ini tidak dilakukan maka energi dari minyak bumi semakin lama akan semakin habis [2].

Salah satu upaya untuk menanggulangi sampah plastik serta memenuhi kebutuhan energi adalah dengan cara membuat energi alternatif dari sampah plastik menjadi bahan bakar minyak [3].

Beberapa penelitian yang berhubungan dengan alat ini adalah Rancang Bangun Tungku Kapasitas 130L pada mesin pembakar sampah [4], Rancang Bangun Kondensor Asap pemanas sampah plastik PET pada mesin pembakar sampah [5], Perancangan Dan Uji Alat Pengolah Sampah Plastik LDPE Menjadi bahan bakar alternative [6], inovasi pengolah sampah plastik menjadi bahan bakar minyak di desa Jampang Bogor [7], Berbagai metode konversi sampah plastik menjadi bahan bakar minyak [8]. Semua penelitian yang sudah disebutkan telah dilakukan tetapi penelitian yang mendesain alat mesin konversi plastik menjadi bahan bakar minyak menggunakan bahan bakar oli bekas belum ada. Oleh karena itu perlu perancangan alat yang sesuai agar bisa memenuhi kebutuhan.

Melihat permasalahan yang ada, kami mencoba mengembangkan alat yang dapat digunakan untuk mendaur ulang sampah plastik tersebut. Untuk sampah plastiknya sendiri kami menggunakan jenis plastik PP dan PET yang kami dapatkan dari beberapa rumah disekitar bantargebang, cileungsi dan bekasi utara. Juga ada beberapa yang kami ambil langsung dari pengumpul sampah plastik.

\section{METODE}

Konsep perancangan alat dibuat untuk mempermudah proses pembuatan dan memaksimalkan proses yang didapat. Perancangan dilakukan dengan tujuan alat mampu mengubah sampah plastik menjadi bahan bakar minyak untuk mengurangi pencemaran lingkungan akibat sampah plastik dan pertambangan bahan bakar minyak, dengan mendaur ulang sampah plastik dengan cara lain yaitu pirolisis. Berikut ini dijelaskan bagaimana tahapan perancangan mesin konversi sampah plastik menjadi bahan bakar minyak.

\section{Diagram Alir}

Proses penelitian ini memerlukan beberapa tahapan kegiatan yang akan dilakukan. Diagaram alir di butuhkan untuk mempermudah dalam kegiatan penelitian ini dapat dilihat pada gambar 1 .

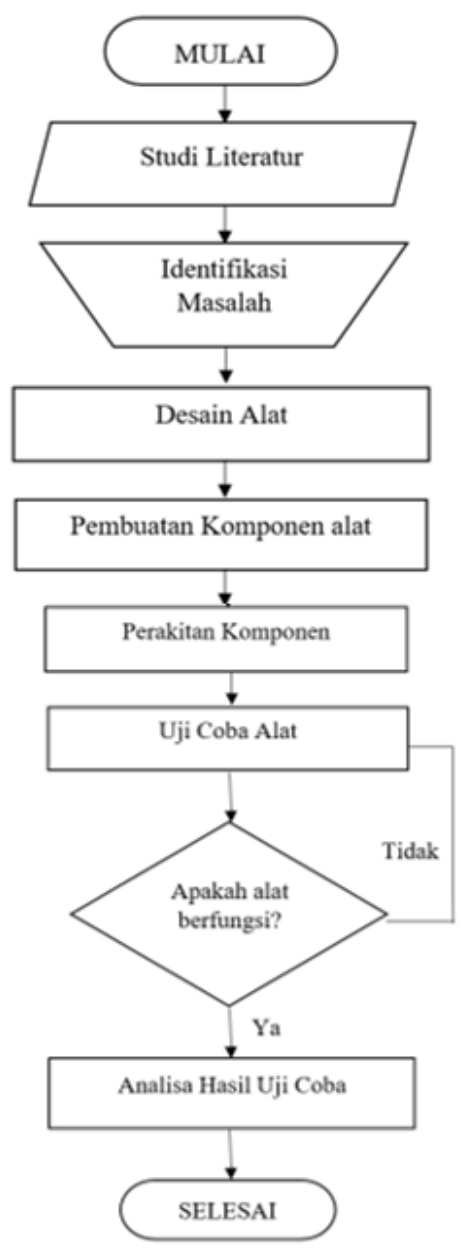

Gambar 1. Diagram Alir Penelitian

\section{Daftar Kebutuhan Produk}

Daftar kebutuhan dibuat dan diberikan nilai kepentingannya, hal ini dilakukan guna mempermudah dalam proses pembuatan. Aspekaspek yang dipertimbangkan dalam menentukan daftar kebutuhan yaitu:

\section{Fungsi}

Alat ini dibuat untuk memanfaatkan sampah plastik PET agar menjadi bahan bakar minyak.

2. Pemanasan yang merata

Bentuk alat yang sesuai agar perpindahan panas dapat terjadi secara merata.

3. Tidak terjadi kebocoran

Alat tidak bocor agar memaksimalkan hasil dari proses pirolisis. 
4. Kuat menahan temperatur tinggi

Alat mampu mehan temperatur hingga $600^{\circ} \mathrm{C}$.

5. Api pembakaran harus tetap menyala

Pada ruang pembakaran yang berada di bawah tungku dibutuhkan suplai udara yang cukup untuk memenuhi kebutuhan udara pada proses pembakaran.

6. Aman digunakan

Alat aman digunakan agar tidak terjadinya insiden kecelakaan kerja pada operator.

7. Mudah dioperasikan

Alat mudah dioperasikan agar memaksimalkan dan mempercepat kinerja operator.

8. Perawatan yang mudah

Alat mudah dilakukan perawatan agar memudahkan operator ketika membersihkan dan menginspeksi komponen pada alat.

9. Mudah dipindahkan

Alat mudah dipindahkan agar bisa fleksibel dan dioperasikan pada tempat yang berbeda.

Tabel 1. Daftar Kebutuhan Produk

\begin{tabular}{c|c|c}
\hline No & Kebutuhan & kepentingan \\
\hline 1 & Fungsi & 5 \\
2 & Pemanasan yang merata & 4 \\
3 & Tidak terjadi kebocoran & 5 \\
4 & Kuat menahan & 5 \\
5 & Apmperatur tinggi & \\
6 & tetap menyala & 4 \\
7 & Aman digunakan & 5 \\
8 & Mudah dioperasikan & 4 \\
9 & Perawatan yang mudah & 4 \\
\hline
\end{tabular}

Keterangan:

$5=$ Sangat Penting

$4=$ Penting

$3=$ Biasa Saja

$2=$ Tidak Penting

$1=$ Sangat Tidak Penting

\section{Desain Alat, Fungsi Dan Spesifikasi}

Desain dibuat untuk merumuskan rencana agar mempermudah proses pembuatan alat. Desain yang sudah dirancang merupakan hasil dari alat peneliti terdahulu yang dimodifikasi pada beberapa komponen, dengan tujuan meningkatkan nilai efisiensinya. Alat yang dirancang memiliki beberapa komponen yaitu: kompor, ruang pembakaran dan ruang pemanasan, ruang filter asap pembakaran, dan kondensor.

\section{Desain Kompor}

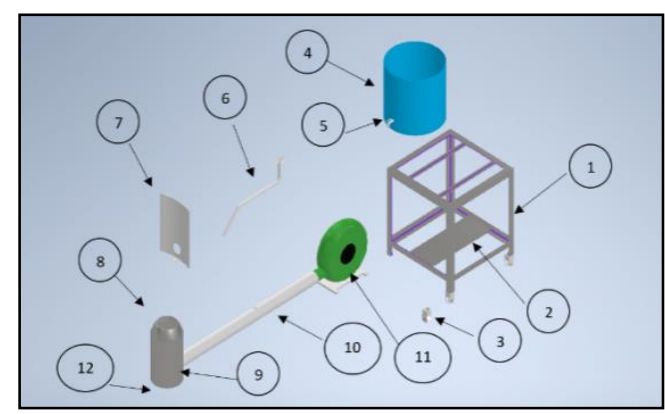

Gambar 2. Desain kompor

Berdasarkan gambar komponen-komponen pada kompor tersebut dijelaskan dengan detail berserta fungsi dengan sebagai berikut:

1. Besi siku 30x30 mm

Berfungsi sebagai penyangga ember oli bekas dengan posisi lebih tinggi dari burner guna memanfaatkan gaya gravitasi agar oli pada ember bisa mengalir ke burner.

2. Besi plat A36 400×250x3 mm Berfungsi sebagai dudukan blower.

3. Roda silikon $\varnothing 1$ inci Berfungsi sebagai alat bantu saat meja kompor ingin dipindahkan.

4. Ember 15 liter

Berfungsi sebagai penyimpanan oli bekas yang akan di suplai ke burner, dengan ember kapasitas 15 liter.

5. $\operatorname{Kran} \varnothing \frac{1}{2}$ inci

Berfungsi sebagai output oli bekas yang akan di alirkan melewati pipa penyaluran menuju burner.

6. Pipa A53 $\varnothing \frac{1}{2}$ inci

Berfungsi sebagai penyalur oli bekas yang akan dialirkan ke burner, dengan ukuran $\varnothing$ $\frac{1}{2}$ inci.

7. Plat A36 (bending) Radius $520^{\circ}, 310 \times 200 \times 4$ $\mathrm{mm}$ 
Berfungsi sebagai penutup ruang pembakaran agar asap yang dihasilkan dari pembakaran tidak keluar dari ruang pembakaran, dengan ukuran.

8. Pipa stainless steel SS 304 (Sch 10) $\varnothing 4$ inci tebal $4 \mathrm{~mm}$.

Berfungsi sebagai mulut burner tempat keluarnya api dari proses pembakaran yang akan memanaskan plastik PET.

9. Pipa stainless steel SS 304 (Sch 10) $\varnothing 6$ inci tebal $4 \mathrm{~mm}$

Berfungsi sebagai badan burner.

10. Pipa A53 panjang $1000 \mathrm{~mm}$ tebal $6 \mathrm{~mm}$ Berfungsi untuk mengalirkan udara dari blower dan mengalirkan oli ke burner.

11. Blower lubang output 2 inci

Berfungsi sebagai alat penghisap udara yang akan di alirkan ke burner.

12. Plat lingkaran Stainless Steel 304

$\varnothing 6$ inci tebal $4 \mathrm{~mm}$

Berfungsi sebagai alas burner.

\section{Desain Ruang Pembakaran}

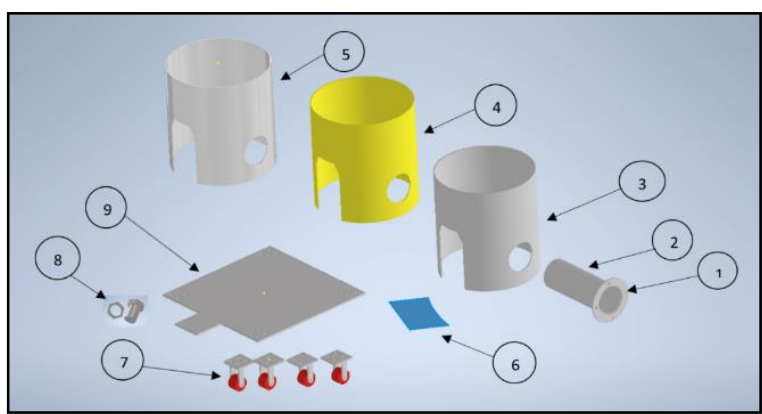

Gambar 3. Desain ruang pembakaran

Berdasarkan gambar komponen-komponen pada ruang pembakaran tersebut dijelaskan dengan detail berserta fungsi dengan sebagai berikut:

1. Flange A36 $\varnothing 5,5$ inci tebal $8 \mathrm{~mm}$ Berfungsi sebagai konektor pipa pembuangan asap pembakaran ke ruang filter asap.

2. Pipa A53 $\varnothing 5,5$ inci tebal $5 \mathrm{~mm}$ inci Berfungsi sebagai tempat penyaluran asap pembakaran ke ruang filter asap.

3. Plat A36 (roll) $\varnothing 500 \mathrm{~mm}$ tebal $6 \mathrm{~mm}$ Berfungsi sebagai badan ruang pemanasan.

4. Glasswoll

Berfungsi sebagai peredam panas dari ruang pembakaran.
5. Plat aluminium

Berfungsi sebagai peredam panas dari ruang pembakaran.

6. Plat A36 250x200x3 mm

Berfungsi sebagai penahan api dari burner agar api tidak mengenai lapisan aluminium pada ruang pemanasan.

7. Roda PU $\varnothing 3$ inci

Berfungsi sebagai alat bantu saat ruang pembakaran ingin dipindahkan.

8. Mur \& Baut Besi M17

Berfungsi sebagai alat penyambung flange pada pipa asap.

9. Plat A36 700x700x10 mm

Berfungsi sebagai alas ruang pembakaran.

\section{Desain Ruang Pemanasan}

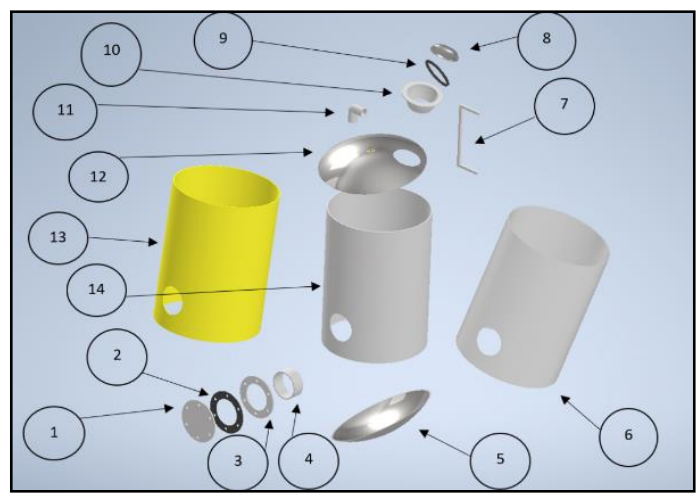

Gambar 4. Desain ruang pemanasan

Berdasarkan gambar komponen-komponen pada ruang pemanasan tersebut dijelaskan dengan detail berserta fungsi dengan sebagai berikut:

1. Blind flange $\varnothing 5,5$ inci tebal $8 \mathrm{~mm}$ Berfungsi sebagai penutup manhole maintenance.

2. seal o ring $\varnothing 5,5$ inci

Berfungsi sebagai alat penutup celah pada manhole maintenance.

3. Flange $\varnothing 5,5$ inci tebal $8 \mathrm{~mm}$ Berfungsi sebagai pintu manhole maintenance.

4. Pipa A53

Berfungsi sebagai tempat maintenance ruang pemanasan.

5. Plat head bodem Stainless steel $304 \varnothing 500$ $\mathrm{mm}$ tebal $4 \mathrm{~mm}$

Berfungsi sebagai alas ruang pemanasan.

6. Plat aluminium

Berfungsi sebagai peredam panas dari ruang pembakaran. 
7. Besi cor panjang $415 \mathrm{~mm}$ tebal $12 \mathrm{~mm}$ Berfungsi sebagai tempat pegangan operator untuk memindahkan tungku pemanasan PET.

8. plat head bodem A36 $\varnothing 5$ inci tebal $4 \mathrm{~mm}$ Berfungsi sebagai penutup manhole input.

9. Seal o ring $\varnothing 5$ inci Berfungsi sebagai alat penutup celah pada manhole input.

10.Flange neck A53 $\varnothing 5$ inci

Berfungsi sebagai tempat masuknya plastik ke ruang pemanasan.

11.Elbow knie galvanis drat dalam $\varnothing \frac{1}{2}$ inci Berfungsi sebagai pipa aliran uap plastik menuju ke kondensor.

12.Plat head bodem Stainless steel $304 \varnothing 500$ $\mathrm{mm}$ tebal $4 \mathrm{~mm}$

Berfungsi sebagai penutup bagian atas ruang pemanasan.

13. Glasswoll

Berfungsi sebagai peredam panas dari ruang pembakaran.

14.Plat A36 (roll) $\varnothing 500 \mathrm{~mm}$ tebal $6 \mathrm{~mm}$

Berfungsi sebagai badan ruang pemanasan.

\section{Desain Ruang Filter Asap}

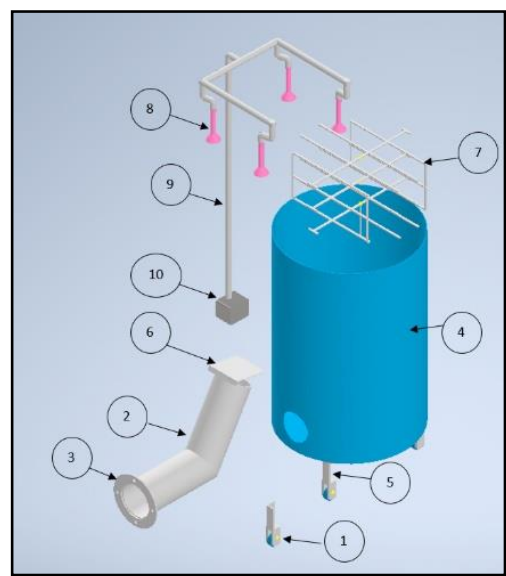

Gambar 5. Desain ruang filter asap

Berdasarkan gambar komponen-komponen pada ruang filter asap tersebut dijelaskan dengan detail berserta fungsi dengan sebagai berikut:

1. Roda silikon $\varnothing 3$ inci
Berfungsi sebagai alat bantu saat ruang filter asap ingin dipindahkan.

2. Plat A36 panjang $650 \mathrm{~mm}$ tebal $5 \mathrm{~mm}$ Berfungsi sebagai tempat masuknya asap dari ruang pembakaran.

3. Flange $A 36 \varnothing 5,5$ inci tebal $8 \mathrm{~mm}$ Berfungsi sebagai konektor pipa pembungan asap pembakaran ke ruang pembakaran.

4. Tangki minyak bekas $\varnothing 600 \mathrm{~mm}$ tinggi 900 $\mathrm{mm}$

Berfungsi sebagai badan ruang filter asap.

5. Besi siku 50x50 mm

Berfungsi sebagai dudukan roda.

6. Plat A36 160x155x2 mm

Berfungsi sebagai pemecah asap dan penahan air agar tidak masuk kedalam pipa.

7. Grating galvanis $1000 \times 550 \mathrm{~mm}$

Berfungsi sebagai layer filter asap yang akan di pasang karung goni.

8. Pemecah air silikon

Berfungsi sebagai output air dari pompa yang berfungsi mengikat asap pembakaran.

9. Pipa aquarium transparan panjang $2000 \mathrm{~mm}$ Berfungsi sebagai pipa aliran air dari pompa menuju pemecah air.

10. Pompa 1500/ Liter

Berfungsi sebagai alat penghisap air yang akan disirkulasikan keruang filter asap.

\section{Desain Kondensor}

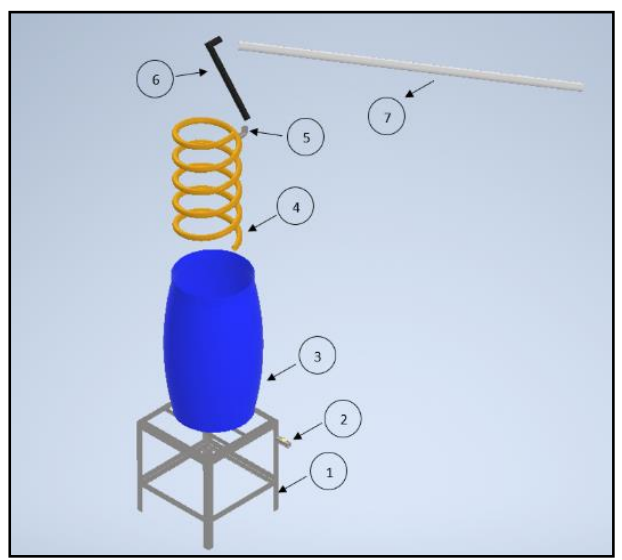

Gambar 6. Desain kondensor

B

erdasarkan gambar komponen-komponen pada kondensor tersebut dijelaskan dengan detail berserta fungsi dengan sebagai berikut:

1. Besi siku 30x30 mm

Berfungsi sebagai penyangga badan kondensor. 
2. $\operatorname{Kran} \varnothing \frac{1}{2}$ inci Berfungsi sebagai tempat keluarnya BBM.

3. Ember kapasitas 35 liter Berfungsi sebagai wadah air di dalam kondensor.

4. Pipa tembaga (spriral) $\varnothing 1,25$ inci Berfungsi sebagai tempat aliran uap plastik yang akan diinginkan pada kondensor.

5. Double niple drat luar

Berfungsi sebagai penghubung selang dan pipa tembaga.

6. Selang hidrolik R2 $\varnothing 1,25$ inci

Berfungsi sebagai tempat aliran uap plastik yang akan di salurkan ke pipa tembaga, dan juga agar mepermudah operator untuk memasangnya karena selang memiliki sifat yang fleksibel.

7. Pipa stainless steel SS 304 (Sch 10) $\varnothing 1,25$ inci

Berfungsi sebagai pipa penyaluran uap plastik dari ruang pemanasan ke kondensor.

Kelebihan desain:

1. Bongkar pasang mudah

2. Mesin bisa dipindah-pindahkan (fleksibel)

3. Daya tahan alat tinggi

4. Perawatan mesin mudah

Kekurangan desain:

1. Massa beban tinggi, sulit jika dipindahkan kelokasi yang berbeda

2. Persiapan untuk pengoperasian alat membutuhkan waktu yang cukup lama.

\section{Analisa Alat}

Persamaan yang digunakan pada penelitian ini untuk menganalisa perpindahan panas konduksi, perpindahan panas konveksi serta debit dirumuskan pada persamaan berikut:

$$
\begin{aligned}
& Q_{\text {konduksi }}=-k A \frac{d T}{d x} \\
& Q_{\text {konveksi }}=h \cdot A \cdot \Delta T \\
& Q=\frac{V}{t} \\
& \frac{P_{1} \cdot \mathrm{V}}{\mathrm{n} \cdot \mathrm{R} \cdot \mathrm{T}_{1}}=\frac{P_{2} \cdot \mathrm{V}}{\mathrm{n} \cdot \mathrm{R} \cdot \mathrm{T}_{2}}
\end{aligned}
$$

Dimana:

$Q_{\text {konduksi }}=$ Laju perpindahan panas konduksi $k=$ Konduktivitas termal bahan

A $=$ Luas penampang

$\frac{d T}{d x} \quad=$ Gradien temperatur dan penampang

$h=$ Koefisien perpindahan panas konveksi

$\Delta \mathrm{T}=$ Perubahan temperature [9]

$\mathrm{Q} \quad=$ Debit $\operatorname{aliran}\left(\frac{\mathrm{m}^{3}}{s}\right)$

$\mathrm{V}=$ Volume $\left(\mathrm{m}^{3}\right)$

$\mathrm{t} \quad=$ Waktu (s) [10]

$P \quad=$ Tekanan $\left(\frac{N}{m^{2}}\right)$

$n \quad=$ Jumlah mol $(\mathrm{mol})$

$R=$ Universal gas constant $\left(8314\left[\frac{\mathrm{J}}{\mathrm{kmol} . \mathrm{K}}\right]\right)$

$T \quad=$ Temperature $(K)$ [11]

\section{Percobaan Alat}

Tujuan perancangan mesin konversi sampah plastik menjadi bahan bakar minyak ini dilakukan untuk mengurangi kerusakan lingkungan yang disebabkan oleh sampah plastik. Berdasarkan tujuan tersebut maka ada beberapa hal yang harus ditentukan pada saat pengujian untuk mengetahui kinerja dan kapasitas alat secara aktual. Pengujian dilakukan dengan beberapa metode, yaitu:

1. Fungsional, yaitu pengamatan secara visual apakah tungku pemanasan mampu memanaskan sampah plastik PET sampai tuntas.

2. Fungsional, yaitu pengamatan secara visual apakah kondensor mampu mengubah uap plastik PET menjadi minyak.

3. Kuantitatif, mengukur bahan bakar yang dibutuhkan untuk memproses $3 \mathrm{~kg}$ plastik ketika alat beroperasi dalam jangka waktu 60 menit menggunakan gelas literan.

4. Kuantitatif, menghitung jumlah bahan bakar minyak yang di hasilkan dari $3 \mathrm{~kg}$ plastik PET dengan jangka waktu 5 menit, 25 menit, 45 menit, dan 60 menit menggunakan alat gelas literan.

\section{HASIL DAN PEMBAHASAN}

\section{Proses Pembuatan Alat}

Mesin konversi sampah plastik menjadi bahan bakar minyak ini memiliki beberapa komponen yang berbeda fungsi, cara kerja, dan proses pembuatannya. Komponen tersebut harus 
dirancang agar dapat berkerja dengan baik. Maka dari itu proses pembuatan mesin konversi sampah plastik menjadi bahan bakar minyak ini perlu diperhatikan agar mendapatkan hasil sesuai kebutuhan.

Dalam proses pembuatan mesin konversi plastic menjadi BBM diperlukan alat-alat kerja yang mengempuni agar proses penelitian berjalan sesuai perencanaan, berikut adalah alat kerja yang dibutuhkan:

Tabel 2. Alat kerja yang dibutuhkan

\begin{tabular}{l|l}
\hline No & Nama Alat Kerja \\
\hline 1. & Mesin Plasma Cutting \\
2. & Mesin Gerinda \\
3. & Mesin Cutting Weel \\
4. & Mesin Bor Magnet \\
5. & Blender Cutting \\
6. & Mesin Bodem plat Maksimal $\varnothing$ \\
& 3500 \\
7. & Mesin Rolling As 350 \\
8. & Mesin Las Tig/Mig 250 A \\
9. & Mesin Las Arcweld Lincoln \\
& Electric \\
10 & Mesin Las Miller XMT \\
11 & Mata Bor 13 m \\
12 & Mata Gerinda Amplas Susun \\
13 & Mata Gerinda Potong \\
14 & Kawat Las Aws 7018 2.6 mm \\
15 & Kawat Las Aws 6013 3.2 mm \\
16 & Kawat Las Aws $3162.4 \mathrm{~mm}$ \\
\hline
\end{tabular}

\section{Proses pembuatan kompor}

Pada penelitian ini kompor yang akan dibuat memiliki beberapa komponen seperti rangka, wadah oli bekas, pipa penyaluran oli bekas, pipa penyaluran udara, blower, dan burner. Komponen tersebut akan dibuat dengan beberapa proses dan dilakukan secara bertahap.

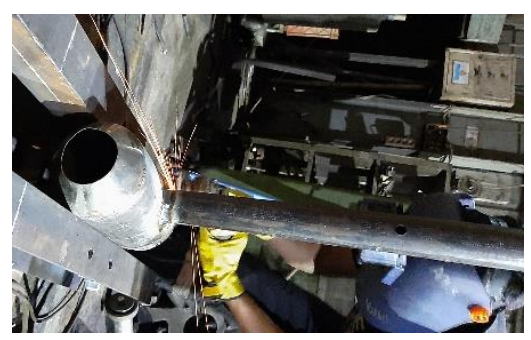

Gambar 7. Proses pembuatan komponen kompor

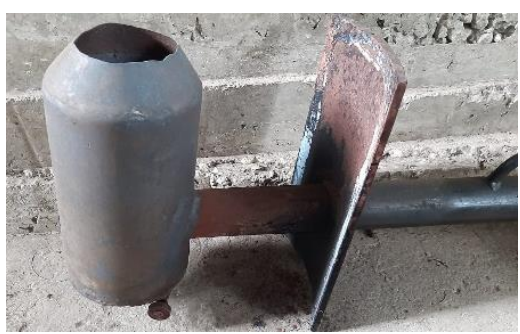

Gambar 8. Komponen burner

\section{Proses pembuatan ruang pembakaran}

Pada penelitian ini ruang pembakaran yang akan dibuat memiliki komponen badan ruang pembakaran dan saluran ouput asap pembakaran Komponen tersebut akan dibuat dengan beberapa proses dan dilakukan secara bertahap.

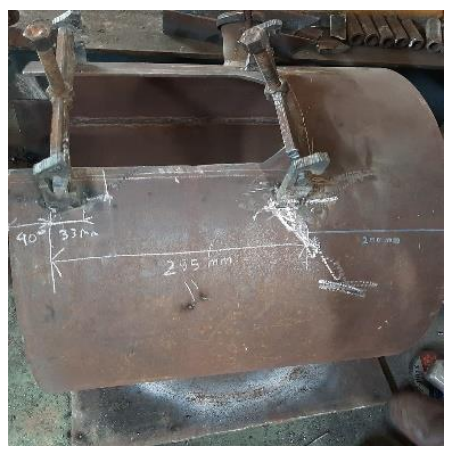

Gambar 9. Proses pembuatan ruang pembakaran

\section{Proses pembuatan ruang pemanasan}

Pada penelitian ini ruang pemanasan yang akan dibuat memiliki beberapa komponen seperti badan ruang pemanasan, manhole input dan manhole maintenance. Komponen tersebut akan dibuat dengan beberapa proses dan dilakukan secara bertahap.

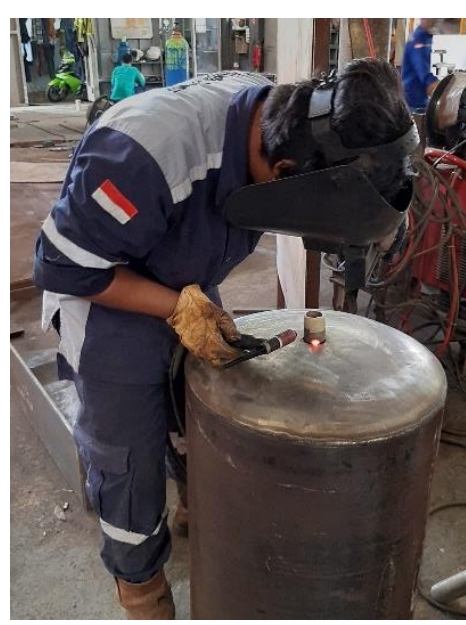

Gambar 10.Proses pembuatan komponen ruang pemanasan 


\section{Proses pembuatan kondensor}

Pada penelitian ini kondensor yang akan dibuat memiliki beberapa komponen seperti rangka kondensor, badan kondensor, pipa penyaluran uap. Komponen tersebut akan dibuat dengan beberapa proses dan dilakukan secara bertahap.

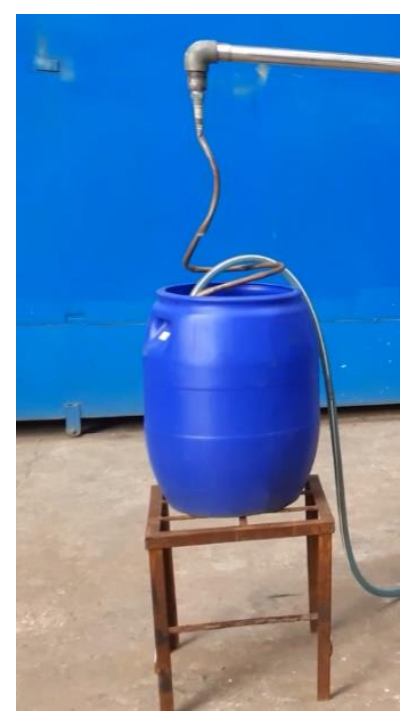

Gambar 11. Kondensor

\section{Proses pembuatan ruang filter asap}

Pada penelitian ini ruang filter asap yang akan dibuat memiliki beberapa komponen seperti rangka badan filter asap, pipa asap, dan layer filter. Komponen tersebut akan dibuat dengan beberapa proses dan dilakukan secara bertahap.

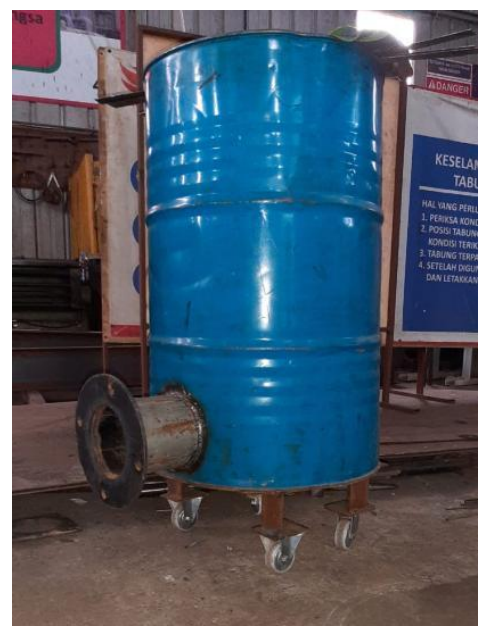

Gambar 12. Ruang filter asap

\section{Perhitungan Analisa}

Adapun beberapa perhitungan yang dapat dicari dari pengujian ini adalah sebagai berikut:

Tekanan ideal pada tungku pembakaran

$$
\frac{p_{1} \cdot \mathrm{V}}{\mathrm{n} \cdot \mathrm{R} \cdot \mathrm{T}_{1}}=\frac{p_{2} \cdot \mathrm{V}}{\mathrm{n} \cdot \mathrm{R} \cdot \mathrm{T}_{2}}
$$

Perhitungan tekanan ideal yang terjadi pada tungku pembakaran ialah:

$$
\begin{aligned}
p_{2} & =\frac{p_{1} \cdot \mathrm{T}_{2}}{\mathrm{~T}_{1}} \\
& =\frac{1.573}{300} \\
& =1,91 \mathrm{~atm} \approx 0,19 \mathrm{MPa} \approx 1.93 \mathrm{Bar}
\end{aligned}
$$

\section{Konduktivitas termal pada pipa penghubung} kondensor

$$
Q_{k o n d u k s i}=-k A \frac{d T}{d x}
$$

$$
q_{\text {konveksi }}=h \cdot \mathrm{A} \cdot \Delta \mathrm{T}
$$

Lalu dapat dihitung pula konduktivitas termal pada pipa penghubung kondensor

$$
h_{1}=\frac{1}{\frac{103-40}{260}-\frac{\operatorname{In}\left(\frac{0,0125}{0,011}\right)}{15}}
$$$$
h_{1}=4.27 \mathrm{~W} / \mathrm{m}^{2} \cdot k
$$

\section{Debit aliran oli}

$$
Q=\frac{V}{t}
$$

Debit aliran oli didapatkan data volume oli $3800 \mathrm{~mL}$ dengan waktu 60 menit

$$
\begin{aligned}
& Q=\frac{V}{t} \\
& Q=\frac{0,0038 \mathrm{~m}^{3}}{3600 \mathrm{~s}} \\
& Q=1,055 \times 10^{-7} \frac{\mathrm{m}^{3}}{\mathrm{~s}}
\end{aligned}
$$




\section{Pengujian Alat}

Percobaan ini akan mengukur berapa bahan bakar oli bekas yang di butuhkan untuk memproses $3 \mathrm{~kg}$ plastik PET dalam jangka waktu 60 menit dan mengukur bahan bakar minyak yang dihasilkan.

Tabel 3. Pengujian Alat

\begin{tabular}{c|c|c}
\hline $\begin{array}{c}\text { Waktu } \\
\text { Menit) }\end{array}$ & $\begin{array}{c}\text { Plastik } \\
\text { PET (Kg) }\end{array}$ & $\begin{array}{c}\text { Hasil Bahan Bakar } \\
\text { Minyak (mL) }\end{array}$ \\
\hline 5 & 3 & - \\
10 & 3 & - \\
15 & 3 & - \\
20 & 3 & 5 \\
25 & 3 & 10 \\
30 & 3 & 30 \\
35 & 3 & 40 \\
40 & 3 & 50 \\
45 & 3 & 65 \\
50 & 3 & 80 \\
55 & 3 & 100 \\
60 & 3 & 140 \\
\hline
\end{tabular}

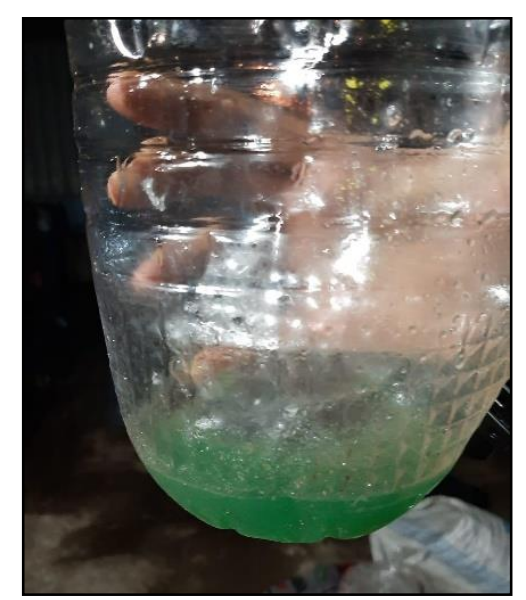

Gambar 13. Sampel hasil bahan bakar minyak

Dari hasil pengujian bahan bakar oli bekas yang dibutuhkan untuk memproses $3 \mathrm{~kg}$ plastik PET dalam waktu 60 menit adalah sekitar $\pm 3000 \mathrm{~mL}$ dan menghasilkan bahan bakar minyak $\pm 140 \mathrm{~mL}$. Kran tempat keluarnya BBM pada kondensor masih mengeluarkan uap yang artinya uap plastik tidak terkondasi secara maksimal.

\section{KESIMPULAN}

Hasil dari pengujian dan analisa penelitian yang telah dilakukan, maka dapat disimpulkan metode yang digunakan pada alat ini adalah pirolisis yang prosesnya memanfaatkan uap plastik yang dipanaskan lalu didinginkan agar uap terkondensasi. Dalam jangka waktu 60 menit bahan bakar oli bekas yang dibutuhkan $\pm 3000 \mathrm{~mL}$ dan menghasilkan bahan bakar minyak $\pm 140 \mathrm{~mL}$. Kran tempat keluarnya BBM pada kondensor masih mengeluarkan uap yang artinya uap plastik tidak terkondasi secara maksimal, disarankan untuk membesarkan volume kondensor, menambahkan pompa pada kondensor agar suhu air pada kondensor tetap setabil, dan menambahkan luas permukaan pipa aliran uap.

\section{DAFTAR PUSTAKA}

[1] Pramiati Purwaningrum, 2016. Upaya Mengurangi Timbulan Sampah Plastik di Lingkungan, JTL. 8 (2), Desember 2016, 141147.

[2] ISSBN, 2018. Energi Terbarukan Dari Sampah Plastik di TPA Puuwatu Dengan Memanfaatkan Teknologi Pirolisis Guna Mendukung Masyarakat Mandiri Energi di Kota Kendari. Kendari, Indonesia 2018. United Nations: Kendari.

[3] Nuha Desi Anggreni, Alfan Ekajati Latief, 2018. Rancang bangun Mesin Pencacah Plastik Tipe Gunting, Jurnal Rekayasa Hijau. 2 (2), Juli 2018, 2550-1070.

[4] Agustiant, Muhammad Brahmana., 2019. Desain Tungku Pembakaran Sampah Kapasitas 130L, Jurnal Politeknik Negeri Jakarta, Depok, Indonesia 2019. United Nations: Depok.

[5] Priyonggo, Hari Agung., 2019. Perancangan kondensor asap hasil pembakaran sampah plastik PET pada mesin pembakar sampah. Jurnal Politeknik Negeri Jakarta, Depok, Indonesia 2019. United Nations: Depok.

[6] Landi, Taufan, Arijanto, 2017. Rancang Bangun Dan Uji Coba Alat Pengolah Sampah Plastik LDPE Menjadi bahan bakar alternative, Jurnal Teknik Mesin S-1. 5 (1), Jan 2017.

[7] Oktora, Reza, 2019. Inovasi Pengolah Sampah Plastik Menjadi Bahan Bakar Minyak Di Desa Jampang Bogor. LPPM Universitas 
Muhammadiyah Jakarta, Jakarta, Indonesia 2019. United Nations: Jakarta.

[8] Oktora, reza, 2013 Inovasi Pengolah Sampah Plastik Menjadi Bahan Bakar Minyak Di Desa Jampang Bogor, Jurnal UMJ. 3 (1) April 2013, 2714-6286.

[9] Y. Cengel and A. Ghajar., 2011 Heat and Mass Transfer Fundamentals and Applications, $4^{\text {th }}$ ed. Singapore: McGraw-Hill.

[10] Giancoli, Douglas., 2001 Fisika Jilid 1 Jakarta: Erlangga.

[11] Michael, Howard, and Yulianto., 2004 Termodinamika Teknik Jilid 2, 2nd ed. Jakarta: Erlangga. 